\title{
Urgensi Bimbingan Pra Nikah bagi Calon Pasangan Pengantin di KUA Kota Salatiga
}

\author{
Nastangin \\ Institut Agama Islam Negeri Salatiga \\ nastangin62@gmail.com
}

Page | 131

\begin{abstract}
Pre-marital guidance is a process of social service in the form of counseling, service provided to husband and wife before carrying out marriage so that they obtain prosperity and happiness in marriage and family life. The phenomenon takes serious attention, accordingly there must be some effort to overcome it, one of the ways is through the application of pre-marital guidance. For this theme, the researcher takes qualitative research to understand the phenomena about what is experienced by research subjects such as behavior, perception, motivation, actions and others, holistically, and in a descriptive way in the form of words and language, especially by utilizing various natural methods in field research. The findings of this research shows the implementation process of pre-marital guidance in religious Affairs office (KUA) of Salatiga City has not been scheduled routinely in most cases. There are 2 forms of pre-marital guidance: first, pre-marital guidance holding at center of religious Affairs office, second, independent pre-marital guidance holding by each religious Affairs office (KUA) in sub-district. In the implementation of pre-marital guidance holding by the religious Affairs office of Salatiga City has several problems namely there are time problems, funds / budget, facilities and infrastructure. The impact of pre-marital guidance in stabilizing the bride and groom to realize a sakinah family in KUA Salatiga City is the preparation of the bride and groom before attending pre-marital guidance. the fact is the bride and groom do not know about the duties of a husband and wife, rights and obligations husband and wife, how to overcome problems in the family and the solution to minimize fight in the family and to minimize the occurrence of divorce.
\end{abstract}

Keywords: Guidance, Marriage and Sakinah Family.

\begin{abstract}
Abstrak
Bimbingan pranikah ialah merupakan tahapan pelayanan bagi seorang calon suami dan isteri sebelum masuk pada akad nikah dengan tujuan memberikan pelayanan beruapa bimbingan, penasehatan, pertolongan sehingga dikemudian hari dalam kehidupan keluarga mendapatan kebahagiaan dan kesejahteraan. Melihat fenomena ini menarik perhatian yang sangat serius, sebab harus ada suatu bentuk upaya untuk menanggulangi hal itu yaitu salah satunya adalah melalui diterapkannya pentingnya bimbingan pra nikah. Penelitian ini menggunakan jenis penelitian kualitatif. Temuan penelitian ini menunjukkan bahwa proses pelaksanaan bimbingan pra nikah di KUA Kota Salatiga secara umum belum terjadwal secara rutin. Ada 2 bentuk bimbingan pra nikah yaitu pertama, bimbingan pra nikah yang dilaksanakan di Bimas Islam Kantor Kementerian Agama, kedua, bimbingan pra nikah mandiri yang dilakukan oleh setiap KUA yaitu pelaksanaanya sebelum akad nikah berlangsung. Dalam pelaksanaan bimbingan pra nikah yang dilaksakan oleh KUA Kota Salatiga mempunyai beberapa kendala yaitu kendala waktu, dana/anggaran, sarana dan prasarana. Dampak bimbingan pra nikah dalam memantapkan calon pengantin untuk mewujudkan keluarga sakinah di KUA Kota Salatiga yakni adanya persiapan dari calon pengantin yang dalam hal ini pasangan calon pengantin sebelum mengikuti bimbingan pra nikah banyak hal yang tidak mereka ketahui tentang tugas-tugas suami isteri, hak dan kwajiban suami isteri, bagaimana cara mengatasi permasalahan dalam keluarga dan solusinya meminimalisir pertengakaran dalam keluarga dan untuk meminimalisir terjadinya perceraian.
\end{abstract}

Kata kunci: Bimbingan, Pernikahan dan Keluarga Sakinah. 


\section{Pendahuluan}

Dalam suatu budaya dan agama perkawinan merupakan suatu hal yang sangat urgen bagi kehidupan manusia di muka bumi. Sebab perkawinan adalah suatu ikatan yang harus ditempuh oleh manusia untuk menghalalkan hubungan

Page|132 lawan jenis (pria dan wanita). ${ }^{1}$ Dalam hal ini semua manusia mempunyai hak yang sama dalam melaksanakan perkawinan. maka dari itu setiap laki-laki maupun perempuan ketika ingin melangsungkan pernikahan diharapkan dengan rasa saling menyayangi dan berdasar suka sama suka. Oleh sebab itu ikatan perkawinan dimaknai akad yang suci dimana perkawinan tersebut dilaksanakan berdasarkan atas dasar kehormatan. ${ }^{2}$ Maka dari itu, maksud dan tujuan pernikahan dalam agama ialah disamping untuk melestarikan keturunan juga memenuhi panggilan dalam agama dengan cita-cita mendapatkan kehidupan keluarga yang sakinah untuk selama-lamanya. ${ }^{3}$ Selanjutnya di dalam Kompilasi Hukum Islam disebutkan bahwa tujuan perkawinan termaktub pada pasal 3, bahwa Perkawinan bertujuan untuk mewujudkan kehidupan rumah tangga yang sakinah, mawaddah, dan rahmah. ${ }^{4}$

Demi terwujudnya tujuan pernikahan tersebut, dengan melihat kondisi masyarakat yang sampai saat ini masih banyaknya angka perceraian maka bimbingan perkawinan sangat penting bagi calon pasangan yang hendak melaksanakan pernikahan. Direktur Jenderal Bimbingan Masyarakat Islam telah mengeluarkan aturan tentang bimbingan perkawinan tertuang dalam Peraturan Direktur Jenderal Bimbingan Masyarakat Islam Nomor : Dj.Ii/542 Tahun 2013. Yang dinamakan dengan bimbingan ialah memberi petunjuk, jalan dan mengarahakan agar tujuan yang diinginkan bisa terwujud baik dalam masa kini maupun masa yang akan datang. Jadi dalam hal ini materi yang diberikan dalam bimbingan untuk jangka waktu lama tidak dalam waktu yang singkat saja tidak hanya itu saja bimbingan tersbeut juga diberikan dalam hal pencegahan, penanganan dan pemecahan masalah. Sesuai dengan tingkat perkembangan budaya manusia, muncullah kemudian upaya-upaya bimbingan yang selanjutnya

${ }^{1}$ Wasman dan Wardah Nuroniyah. Hukum Perkawinan Islam di Indonesia, cet. ke-1. Yogyakarta: CV. Citra Utama, 2011. hlm. 279

2 Muhammad Syahrur. Prinsip dan Dasar Hermeneutika Hukum Islam Kontemporer. Yogyakarta: Kalimedia, 2016. hlm. 281.

${ }^{3}$ Abdul Rahman Ghozali. Fiqh Munakahat. Jakarta: Kencana, 2010. hlm. 22.

${ }^{4}$ Pasal 3 Kompilasi Hukum Islam (KHI). 
disebut dengan bimbingan formal, bentuk isi dan tujuan, serta aspek-aspek penyelenggaraan bimbingan formal itu mempunyai rumusan yang nyata. ${ }^{5}$

Kursus Pra Nikah diatur dalam Pasal 1 ayat (1) bahwa memberikan bekal pengetahuan, pemahaman, keterampilan dan penumbuhan kesadaran kepada remaja usia nikah tentang kehidupan rumah tangga dan keluarga. ${ }^{6}$ Hal itu dibuka dengan tujuan sebagai salah satu upaya untuk meminimalisir perceraian yang banyak terjadi di masyarakat. Sebab semua para calon pengantin diberi nasehat dan bekal dalam menjalin kehidupan keluarga melalui bimbingan perkawinan tersebut. Dengan kondisi realitas di masyarakat Kota Salatiga sampai saat ini angka perceraian di Pengadilan Agama masih tinggi. Entah itu cerai gugat ataupun cerai talak alasan perceraiannyapun beragam. Misalnya perceraian disebabkan karena faktor ekonomi, usia dini, nafkah dan sebagainya. Pada akhirnya tujuan pernikahan untuk membentuk suatu keluarga yang sakinah, mawadah dan warahmah belum bisa tercapai.

Melihat fenomena ini menarik perhatian yang sangat serius, sebab harus ada suatu bentuk upaya untuk menanggulangi hal itu yaitu salah satunya adalah melalui diterapkannya pentingnya bimbingan pra nikah. Sehingga penulis tertarik untuk melakukan penelitian mendalam diharapkan nantinya akan diketahui kenapa hal itu bisa terjadi. Apakah pentingnya bimbingan pra nikah tersebut sudah benar-benar dilaksanakan dengan optimal oleh lembaga yang berwenang salah satunya adalah Kantor Urusan Agama (KUA) atau sudah dilaksanakan akan tetapi belum berjalan dengan baik. Disini penulis ingin mengetahui dari beberapa pokok masalah untuk nanti ditemukan jawabannya yaitu bagaimana pelaksanaan bimbingan pra nikah di KUA Kota Salatiga, apa kendala yang di hadapi dalam melaksanakan bimbingan pra nikah, apa urgensi dilaksankannya bimbingan pra nikah dan apa dampak dilaksanakannya bimbingan pra nikah tersebut. Disini penulis juga menggunakan teori-teori untuk menjawab permasalahan tersebut. Kata bimbingan dalam bahasa Inggris yaitu "guidance". Guidance berasal dari kata kerja "to guide" yang artinya memberi petunjuk, jalan kepada seseorang agar hidupnya lebih baik dimasa kini dan yang akan datang. ${ }^{7}$ Menurut Prayitno, dalam bukunya "Dasar-dasar Bimbingan \& Konseling" bimbingan yaitu bantuan yang

${ }^{5}$ M.Ridho Iskandar. Urgensi Bimbingan Pra Nikah Terhadap Tingkat Pencerian, JIGC (Journal of Islamic Guidance and Counseling) Universitas Negeri Jakarta, (UNJ), 2 (1) 2018. hlm. 2.

${ }^{6}$ Pasal 1 Ayat (1) Peraturan Direktur Jenderal Bimbingan Masyarakat Islam Nomor : Dj.ii/542 Tahun 2013 Tentang Pedoman Penyelenggaraan Kursus Pra Nikah.

${ }^{7}$ Arifin. Pedoman Pelaksanaan Bimbingan dan Penyuluhan Agama. Jakarta: PT, Golden rayon Press, 1998. hlm. 1. 
diberikan kepada seseorang baik itu anak-anak atau remaja maupun dewasa yang dilakukan oleh seorang yang memang benar ahli dengan maksud untuk menjadikan orang-orang tersebut lebih baik dan berkembang. ${ }^{8}$ Di dalam Pasal 1 ayat (1) Peraturan Direktur Jenderal Bimbingan Masyarakat Islam Nomor :

Page|134 Dj.Ii/542 Tahun 2013 Tentang Pedoman Penyelenggaraan Kursus Pra Nikah. Disebutkan bahwa kursus Pra Nikah adalah pemberian bekal pengetahuan, pemahaman, keterampilan dan penumbuhan kesadaran kepada remaja usia nikah tentang kehidupan rumah tangga dan keluarga. ${ }^{9}$

Jadi, yang dimaksud dengan bimbingan pranikah ialah suatu proses pemberian petunjuk dan juga pencegahan dalam hal perkawinan kepada calon suami isteri agar mengetahui dengan benar baik dari persiapan perkawinan sampai dengan di kehidupan keluarga. ${ }^{10}$ Secara teoritis, pendidikan meliputi beberapa unsur sebagai berikut: subjek yang dibimbing (peserta didik), orang yang membimbing (pendidik), interaksi antara peserta didik dengan pendidik (interaksi edukatif), ke arah mana bimbingan ditujukan (tujuan pendidikan), pengaruh yang diberikan dalam bimbingan (materi/kurikulum pendidikan), cara yang digunakan dalam bimbingan (metode pendidikan), serta tempat dimana peristiwa bimbingan berlangsung (lingkungan pendidikan). ${ }^{11}$

\section{Metode Penelitian}

Dalam hal ini penulis menggunakan metode penelitian dengan jenis penelitian kualitatif, yaitu penelitian yang ingin mengetahui dan sekaligus memahami fenomena yang terjadi dalam masyarakat dan diselesaikan dengan komprehensif dengan memanfaatkan dari metode ilmiah. ${ }^{12}$ Dilihat dari sifatnya penelitian ini bersifat deskriptif. Deskriptif dapat diartikan sebagai prosedur pemecahan masalah yang diselidiki dengan

${ }^{8}$ Prayitno, Erman Amti. Dasar-dasar Bimbingan \& Konseling. Jakarta: Rineka Cipta, 2013. hlm. 99.

9 Pasal 1 Ayat (1) Peraturan Direktur Jenderal Bimbingan Masyarakat Islam Nomor: Dj.Ii/542 Tahun 2013 Tentang Pedoman Penyelenggaraan Kursus Pra Nikah.

${ }^{10}$ Mahmudin. "Implementasi Pembekalan Pranikah Dalam membentuk Keluarga Sakinah Mawaddah Warahmah", Millah, Jurnal Studi Agama UII, XV, (2). 2016. hlm. 299-318.

${ }^{11}$ Umar Tirtaraharja dan S.L. La Sulo. Pengantar Pendidikan. Jakarta: Rineka Cipta, 2005. hlm. 11

${ }^{12}$ Lexy J. Meoleong. Metode Penelitian Kualitatif. Bandung: Remaja Rosda Karya, 2013. hlm. 6 
menggambarkan atau melukiskan keadaan subjek atau objek penelitian pada saat sekarang pada fakta-fakta yang tampak. ${ }^{13}$

Jadi jenis penelitian ini mencoba memahami dan menafsirkan suatu peristiwa yang terjadi di masyarakat terkait tingkah laku dan hidup seseorang menurut peneliti sendiri. ${ }^{14}$ Penelitian ini menggambarkan secara objektif tentang urgensi bimbingan pra nikah bagi calon pasangan pengantin demi terwujudnya kehidupan keluarga sakinah, mawadah, warahmah yang dilakukan di KUA Kota Salatiga).

\section{Hasil dan Pembahasan}

Menurut Syubandono, bimbingan pranikah adalah merupakan suatu pelayanan kepada seseorang yang hendak ingin melangsukan perkawinan pelayanan tersebut berupa penasehatan terkait dalam kehidupan keluarga demi terwujudnya kehidupan yang bahagia dan sejahtera. ${ }^{15}$ Setiap seseorang mempunyai kemampuan sendiri-sendiri dalam menghadi suatu problem yang dialami. Ada yang bisa menyelesaikan sendiri juga ada yang harus dengan bantuan orang lain. Sehingga dalam hal ini diadakan bimingan pra nikah agar nantinya setelah menjalin kehidupan rumah tangga dapat menghadapi dan menyelesaikan masalah tersebut dengan mudah. ${ }^{16}$

Konsep bimbingan pranikah adalah kegiatan yang dilakukan oleh pembimbing kepada calon suami isteri agar memiliki pengetahuan tantang pernikahan dan mampu membina sebuah keluarga tentram dan bahagia. Dasar Pelaksanaan Bimbingan Pra Nikah antara lain: a) Undang-Undang Nomor 1 Tahun 1974 tentang Perkawinan (Lembaran Negara Republik Indonesia Tahun 2019); b) Undang-Undang Nomor 10 Tahun 1992 tentang Perkembangan Kependudukan dan Pengembangan Keluarga Sejahtera; c) Undang-Undang Nomor 23 Tahun 2002 tentang Perlindungan Anak (Lembaran Negara Republik Indonesia tahun 2002 Nomor. 109, Tambahan Lembaran Negara Republik Indonesia Nomor. 4235); d) Undang-Undang Nomor. 23 Tahun 2004 tentang Penghapusan Kekerasan dalam Rumah Tangga (Lembaran Negara Republik Indonesia Tahun 2004 Nomor. 95, Tambahan Lembaran Negara Republik

13 Hadari. Metode Penelitian Bidang Sosial Cet. Ke-8. Yogyakarta: Gajah Mada University Press, 1998. hlm. 63.

${ }^{14}$ Kantini Kartono. Pengatar Metodologi Riset Sosial. Bandung: Madar Maju, 1996. hlm.78.

15 Syubandono, Ahmad Hamdany. Pokok-Pokok Pengertian dan Metode Penasehatan Pernikahan "Marriage Counseling". hlm. 3.

${ }^{16}$ Walgito, Bimo. Bimbingan dan Konseling Perkawinan. Yogyakarta: Andi Offset, 2004. hlm. 7.

JURNAL IQTISAD: Reconstruction of Justice and Welfare for Indonesia - Vol. 8 No. 2 (2021) 
Indonesia No. 4419); e) Instruksi Presiden Nomor. 9 Tahun 2000 tentang Pengarusutamaan Gender dalam Pembangunan Nasional; f) Keputusan Presiden RI Nomor 88 Tahun 2002 tentang Rencana Aksi Nasional Penghapusan Perdagangan Perempuan dan Anak; g) Peraturan Presiden Nomor 20 tahun

Page | 1362008 tentang perubahan keempat atas Peraturan Presiden Nomor 9 Tahun 2005 tentang Kedudukan, Tugas, Fungsi, Susunan Organisasi dan Tata Kerja Kementrian Negara RI; h) Peraturan Presiden Nomor. 24 Tahun 2006 tentang Kedudukan, Tugas, Fungsi, Susunan Organisasi, Tugas dan Fungsi Eselon I Kementrian Negara; i) Keputusan Mentri Agama Nomor. 3 Tahun 1999 tentang Gerakan Keluarga Sakinah; j) Keputusan Mentri Agama Nomor 480 Tahun 2008 tentang Perubahan Atas Keputusan Mentri Agama Nomor. 373 Tahun 2002 tentang Organisasi dan Tata Kerja Kantor Wilayah Kementrian Agama Provinsi dan Kantor Departemen Agama Kabupaten/Kota; k) Peraturan Mentri Agama Nomor 10 Tahun 2010 tentang Organisasi dan Tata Kerja Kementrian Agama; I) Surat Edaran Mentri Dalam Negeri Nomor. 4005/54/III/Bangda perihal Pelaksanaan Pembinaan Gerakan Keluarga Sakinah (Peraturan Dir. Jen BIMAS Islam tahun 2013).

Tujuan bimbingan pranikah menurut Amnur Rahim Faqih antara lain membantu klien untuk mencegah timbulnya problem-problem yang berkaitan dengan pernikahan, yaitu: 1) Membantu calon pengantin memahami tujuan pernikahan menurut Islam; 2) Membantu calon pengantin memahami hakikat pernikahan dalam Islam; 3) Membantu calon pengantin memahami persyaratan-persyaratan pernikahan menurut Islam; 4) Membantu calon pengantin memahami kesiapan dirinya untuk menjalankan pernikahan.

Membantu calon pengantin melaksanakan pernikahan sesuai dengan ketentuan syariat Islam. membantu individu mencegah timbulnya problemproblem yang berkaitan dengan kehidupan rumah tangganya, yaitu: 1) Membantu calon pengantin memahami melaksanakan pembinaan kehidupan rumah tangga sesuai dengan ajaran Islam; 2) Mengembangkan nilai dan sikap menyeluruh serta perasaan sesuai dengan penerimaan diri; 3) Membantu di dalam memahami tingkah laku manusia; 4) Membantu klien untuk hidup di dalam kehidupan yang seimbang dalam berbagai aspek, fisik, mental dan sosial. $^{17}$

\footnotetext{
${ }^{17}$ Faqih, Aunur Rahim. Bimbingan dan Konseling dalam Islam. Yogyakarta: UII Press, 2001.
} hlm. 54. 
Sedangkan bimbingan pra nikah menurut Dewa Ketut Sukardi mempunyai beberapa fungsi yaitu: a. Fungsi Preventif: sebagai pencegah terhadap timbulnya problem; b. Fungsi Pemahaman: menghasilkan pemahaman tentang sesuatu; c. Fungsi perbaikan: menghasilkan solusi dari berbagai problem yang dialami; d. Fungsi Pemeliharaan dan pengembangan: membantu dalam memelihara dan mengembangkan keseluruhan pribadinya secara mantap, terarah, dan berkelanjutan. ${ }^{18}$

Kata sakinah diambil dari akar kata yang terdiri atas huruf sin, kaf, dan nun yang mengandung makna ketenangan, atau anonim dari guncang dan gerak. Berbagai bentuk kata yang terdiri atas ketiga huruf tersebut semuanya bermuara pada makna di atas. Rumah dinamai maskan karena ia merupakan tempat untuk meraih ketenangan setelah sebelumnya sang penghuni bergerak (beraktivitas di luar). ${ }^{19}$ Sedangkan menurut Quraish Shihab, sakinah terambil dari akar kata sakana yang berarti diam atau tenangnya sesuatu setelah bergejolak. ${ }^{20}$ Penggunaan kata sakinah dalam pembahasan keluarga pada dasarnya diambil dari Al-Quran surat al-Rum ayat 21 "litaskunu ilaiha" artinya bahwa Allah menciptakan perjodohan bagi manusia agar yang satu merasa tentram terhadap yang lain.

Dalam bahasa Arab, kata sakinah di dalamnya terkandung arti tenang, terhormat, aman, penuh kasih sayang, mantap dan memperoleh pembelaan. Dengan demikian dapat dipahami, bahwa keluarga sakinah adalah suatu kondisi yang paling ideal dalam hidup di keluarga ${ }^{21}$ Kata sakinah yang digunakan dalam mensifati kata "keluarga" merupakan tata nilai yang seharusnya menjadi kekuatan penggerak dalam membangun kehidupan keluarga yang mampu memberikan kenyamanan dunia sekaligus memberikan jaminan keselamatan akhirat. ${ }^{22}$ Jadi dapat disimpulkan bahwa keluarga sakinah adalah keluarga yang diawali melalui perkawinan yang sah dan setiap suami atau isteri mampu menjalankan tugas hak kewajiban masing-masing dengan baik.

\footnotetext{
${ }^{18}$ Sukardi, Dewa K. Pengantar Pelaksanaan Program Bimbingan dan Konseling di Sekolah. Jakarta: PT Rineka Cipta, Edisi Revisi, 2008. hlm. 26-27.

${ }^{19}$ Said Husin Al-Munawwar. Agenda Generasi Intelektual: Ikhtiar Membangun Masyarakat Madani. Jakarta: Pena Madani, 2003. hlm 62.

${ }^{20}$ Quraish Shihab. Wawasan Al-Quran. Bandung: Mizan. hlm. 192.

${ }^{21}$ Ibid., Said Husin Al-Munawwar. hlm. 62.

22 Miftah Faridl. "Merajut Benang Kaluarga Sakinah" jurnal Al-Insan 3, (2), Jakarta: Lembaga Kajian dan Pengembangan Al-Insan, 2006. hlm. 75.
} 
Di Kota Salatiga ada empat Kantor Urusan Agama (KUA) antara lain: KUA Tingkir, KUA Argomulyo, KUA Sidomukti dan KUA Sidorejo yang terdapat di empat Kecamatan di Kota Salatiga. Waktu Pelaksanaan kegiatan kursus, calon pengantin di KUA Kota Salatiga belum terjadwal secara rutin, sehingga tidak

Page 138 dapat ditentukan dalam satu tahun berapa kali menyelenggarakan kursus calon pengantin. Dengan demikian hasil dari wawancara peneliti ada dua jenis bimbingan pra nikah yang di lakukan di KUA Kota Salatiga yaitu:

Bimbingan pra nikah yang dilaksanakan oleh Kementerian Agama dibawah Bimas Islam. Bimbingan pra nikah tersebut dilaksankan 2-3 kali dalam satu tahun. Peserta yang ikut dalam bimbingan tersebut sekitar 25 pasang dalam setiap pelaksanaan kadang juga menyesuaikan jumlah yang sudah mendaftar untuk mengikuti bimbingan. ${ }^{23}$ Materi kursus calon pengantin yang diberikan meliputi tujuh aspek yakni tata cara dan prosedur perkawinan, pengetahuan agama, peraturan perundang-undangan dalam bidang perkawinan dan keluarga, hak dan kewajiban suami isteri, kesehatan dan reproduksi, manajemen keluarga, dan psikologi perkawinan dan keluarga. Untuk durasi waktu pelaksanaanya dua hari dengan metode penyampaian materinya adalah dengan ceramah. Berdasarkan ketentuan dalam Peraturan Dirjen Bimas Islam Nomor DJ. II/ 491/ 2009 tentang Kursus Calon Pengantin, para peserta yang telah mengikuti kegiatan kursus calon pengantin mendapatkan sertifikat, yang merupakan tanda lulus mengikuti kegiatan kursus calon pengantin. ${ }^{24}$

Bimbingan pra nikah yang dilakukan secara mandiri oleh KUA Kota Salatiga. Mandiri artinya adalah bahwa bimbingan tersebut dilaksanakan tidak secara klasikal dan tidak harus sesuai dengan jumlah pasangan yang sudah mendaftar bimbingan, namun bimbingan tersebut dilaksanakan ketika setelah pemeriksaan pernikahan dan sebelum akad nikah. ${ }^{25}$ Untuk durasi waktu bimbingan tersebut beragam antara setengah hingga satu jam lebih. Materi yang diberikan dalam bimbingan ini adalah mengenai bagaimana cara hidup berkeluarga, pentingnya keluarga, pentingnya perkawinan dalam agama, hak dan kewajiban suami isteri, cara penyelesaian masalah dalam keluarga dan sebagainya.

Selain daripada itu, di KUA Kota Salatiga juga tiap tahunnya rutin mengirim pasangan calon pengantin untuk mengikuti kursus calon pengantin

\footnotetext{
${ }^{23}$ Wawancara dengan Kepala KUA Kota Salatiga

${ }^{24}$ Dirjen Bimas Islam, Peraturan Dirjen Bimas Islam No. DJ. II/ 491/ 2009 tentang Kursus Calon Pengantin.

${ }^{25}$ Wawancara dengan Kepala KUA Kota Salatiga
} 
yang diselenggarakan di Kantor Kementerian Agama Kota Salatiga dengan jumlah yang sudah mendaftar untuk mengikuti bimbingan pra nikah tersebut sejumlah 10 hingga 20 pasang calon pengantin. Itulah proses pelaksanaan bimbingan pra nikah yang dilaksankan di KUA Kota Salatiga, sehingga untuk proses pelaksanaannya belum secara keseluruhan sesuai dengan peraturan yang ada dalam Peraturan Dirjen Bimas Islam Nomor DJ. II/ 491/ 2009 tentang Kursus Calon Pengantin. ${ }^{26}$

Secara umum dalam pelaksanaan bimbingan pra nikah di KUA Kota Salatiga mempunyai beberapa kendala yang dihadapi diantaranya Kendala yang pertama ini adalah waktu dalam pelaksanaan bimbingan pra nikah. Waktu ini menjadi kendala artinya adalah waktu bagi pihak penyelenggara dan waktu bagi calon pasangan pengantin. Bahwa dalam pelaksanaan bimbingan ini untuk pihak pelaksana terkendala karena anggaran, maksudnya ketika belum ada anggaran maka pelaksanaan bimbingan pra nikah belum bisa dilaksanakan jadi waktu pelaksanaan tidak bisa ditetapkan setiap tahun ketika bulan apa bimbingan tersebut dilaksanakan. Kemudian kendala waktu bagi calon pasangan pengantin adalah sulit untuk mengatur jadwal ketika sudah ditentukan oleh pihak penyelenggara bimbingan dikarenakan mayoritas calon pasangan pengantin sudah terikat oleh jam kerja, sehingga ketika ingin ikut bimbingan pra nikah mereka harus izin dalam pekerjaannya. ${ }^{27}$ Sehingga ketika kegiatan bimbingan pra nikah diselenggarakan tidak jarang peserta kursus memilih untuk tidak menghadiri kegiatan bimbingan pra nikah tersebut karena lebih memilih untuk melaksanakan kegiatan atau aktivitasnya seperti biasa, dibandingkan dengan mengikuti kegiatan kursus calon pengantin. Apalagi bimbingan pra nikah bukan merupakan suatu syarat untuk pendaftaran nikah. Hal inilah yang menyebabkan bimbingan pra nikah menjadi tidak bisa dilaksanakan sebagaimana mestinya.

Kegiatan kursus calon pengantin berdasarkan Peraturan Dirjen Bimas Islam Nomor DJ. II/ 491/ 2009 ini merupakan kegiatan yang bertujuan baik sekaligus sebagai langkah prefentif (pencegahan), dengan cara pemberian pembekalan kepada para calon pengantin yang meliputi tujuh aspek. Akan tetapi kegiatan yang bertujuan sebagai solusi untuk mengurangi angka perceraian ini tidak dimbangi dengan pemberian dana dari pemerintah untuk menyelenggarakan kegiatan kursus calon pengantin tersebut. Secara umum penuturan dari kepala KUA Kota Salatiga mengatakan bahwa kendalanya adalah dana dari pemerintah yang diberikan untuk pelaksanaan bimbingan pra nikah.

\footnotetext{
${ }^{26}$ Wawancara dengan Kepala KUA Kota Salatiga

${ }^{27}$ Wawancara dengan Kepala KUA Kota Salatiga
} 
Sehingga dalam pelaksanaanya kurang maksimal, sebab hal tersebut tidak bisa dilaksanakan kalau belum ada dana pemerintah. Hal tersebut berimbas pada proses pelaksanaan yang menjadi tidak konsisten dalam penyelenggaraanya dan waktunya tidak bisa ditentukan secara pasti dalam setiap tahun tergantung Page|140 sudah ada dananya atau belum. Jadi meskipun sudah banyak yang mendaftar bimbingan pra nikah akan tetapi dana belum ada maka bimbingan tersebut tidak bisa dilaksanakan mengingat kegiatan ini banyak kebutuhan yang harus dipenuhi. $^{28}$

Dalam melaksanakan suatu kegiatan sarana prasarana menjadi sebuah komponen yang penting. Dalam Peraturan Dirjen Bimas Islam Nomor DJ. II/ 491/ 2009 tentang Kursus Calon Pengantin dalam pasal 4, menjadikan KUA dan BP-4 selaku penyelenggara dalam kegiatan kursus calon pengantin tesebut. Akan tetapi keterbatasan sarana dan prasarana yang terdapat di KUA menjadi sebuah kendala tersendiri dalam upaya implementasi peraturan tentang bimbingan pra nikah sebagai solusi untuk mengurangi angka perceraian. Dalam pelaksanaan bimbingan pra nikah ini yang menjadi kendala juga adalah masalah sarana dan prasarana. Karena di Kantor KUA tidak ada sebuah gedung atau ruangan yang memadai dalam pelaksanaan bimbingan, sehingga dalam pelaksanaannya diadakan secara mandiri kepada masing-masing pasangan calon pengantin sebelum akad nikah berlangsung. Pada akhirnya KUA tidak bisa melaksanakan bimbingan secara klasikal di Kantor sehingga untuk bimbingan pra nikas yang diadakan secara klasikal adalah di Kementerian Agama Kota Salatiga. ${ }^{29}$

Dengan melihat kondisi tersebut maka dapat diambil benang merah bahwa dalam pelaksaan bimbingan pra nikah itu belum bisa dijalankan secara maksimal disebabkan banyak kendala yang dihadapi oleh KUA sendiri dan kendala tersebut sebenarnya bukan dari intern KUA sendiri, akan tetapi kendala tersebut lebih datngnya dari pihak luar KUA yaitu para pasangan calon pengantin sendiri dan juga dari pemerintah. Akhirnya bimbingan ini belum bisa secara maksimal dijalankan sesuai dengan aturan yang berlaku yaitu Peraturan Dirjen Bimas Islam Nomor DJ. II/ 491/ 2009. Akan tetapi pihak KUA sendiri selalu mempunyai inisiatif sendiri dalam pelaksanaan bimbingan pra nikah agar tetap bisa berjalan yaitu dengan cara bimbingan pra nikah yang dilakukan secara mandiri bagi calon pasangan pengantin yang diadakan sebelum akad berlangsung.

\footnotetext{
${ }^{28}$ Wawancara dengan Kepala KUA Kota Salatiga

${ }^{29}$ Wawancara dengan Kepala KUA Kota Salatiga
} 
Dalam pelaksanaan bimbingan pra nikah tentu sangat penting diberikan kepada calon pengantin. Karena tidak semua calon pengantin sudah paham tentang bagaimana cara berkehidupan dalam keluarga yang baik, cara mewujudkan keluarga yang sakinah, cara dalam mengatasi problem yang terjadi dalam keluarga dan masih banyak lagi hal-hal yang terkait dengan kehidupan keluarga. Sehingga bimbingan pra nikah ini sangat penting diberikan kepada setiap calon pasangan pengatin yang ingin melangsungkan perkawinan.

Dalam hal ini penulis menemukan jawaban yang diberikan oleh Kepala KUA Kota Salatiga bahwa bimbingan pra nikah sangat penting ${ }^{30}$ antara lain: 1) Adanya pengetahuan baru bagi calon pasangan pengantin terkait bagaimana cara hidup dalam keluarga; 2) Pentingnya perkawinan dalam agama; 3) Cara memupuk kehidupan keluarga yang bahagia; 4) Cara menuju dan membentuk kehidupan keluarga yang sakinah; 5) Cara mengatasi problem dalam keluarga; 6) Pembinaan mental.

Itulah merupakan suatu hal sangat penting dalam bimbingan pra nikah dilaksanakan demi terwujudnya kehidupan keluarga yang sakinah. Karena tanpa bekal pengetahuan seperti itu tidak menutup kemungkinan kehidupan dalam keluarga bisa terputus ditengah jalan. Dalam pelaksanaanya bimbingan yang disampaikan oleh pembimbing pranikah kepada calon pengantin, sesuai dengan salah satu fungsi bimbingan konseling keluarga islam yaitu fungsi preventif yakni membantu individu mencegah timbulnya problem yang berkaitan dengan pernikahan, dengan jalan membantu individu memahami hakikat pernikahan, tujuan pernikahan, persyaratan pernikahan, kesiapan diri untuk menjalankan atau melaksanakan pernikahan dan dapat memahami pernikahan sesuai dengan ajaran Islam. ${ }^{31}$

Bimbingan pranikah juga memberikan kesadaran kepada calon pengantin tentang arti pentingnya tanggung jawab, serta hak dan kewajiban masingmasing pasangan dan adanya musyawarah diperlukan untuk memecahkan masalah yang dihadapi dalam kehidupan rumah tangga. Dalam mewujudkan keluarga sakinah perlu dibiasakan, karena sakinah tidak terwujud dengan sendirinya tetapi dengan adanya usaha dari keduanya. Dengan adanya bimbingan pranikah sangat penting bagi calon pengantin dalam mempersiapkan kehidupan baru baik dari segi fisik maupun psikis. Dalam mempersiapkan kehidupan baru ini tentunya tidak hal yang mudah dengan adanya bimbingan

\footnotetext{
${ }^{30}$ Wawancara dengan Kepala KUA Kota Salatiga

${ }^{31}$ Wawancara dengan Kepala KUA Kota Salatiga
} 
pra nikah diharapkan terwujudnya cita-cita dalam kehidupan keluarga yaitu untuk membentuk keluarga sakinah mawadah warahmah. Dalam hal ini KUA ${ }^{32}$ sudah berusaha dengan baik dan maksimal dalam penyelenggaraan bimbingan pra nikah karena hal tersebut sangat penting sebagai bekal bagi para calon

Page|142 pengantin dalam mengarungi bahtera rumah tangga untuk menjembatani supaya kehidupan berkeluarga menjadi langgeng dan tidak terjadi perceraian hal itu sejalan dengan Pasal 1 Undang-Undang Perkawinan Nomor 1 Tahun 1974 yang menyatakan bahwa Perkawinan adalah ikatan lahir batin antara seorang pria dan seorang wanita sebagai suami istri dengan tujuan membentuk keluarga atau rumah tangga yang bahagia dan kekal berdasarkan Ketuhanan Yang Maha Esa. ${ }^{33}$ Firman Allah SWT:

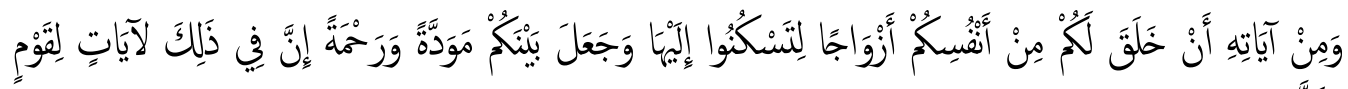

$$
\begin{aligned}
& \text { يَتَفَرَّرونَ }
\end{aligned}
$$

Artinya: Dan di antara tanda-tanda kekuasaan-Nya ialah Dia menciptakan untukmu istri-istri dari jenismu sendiri, supaya kamu cenderung dan merasa tenteram kepadanya, dan dijadikan-Nya di antaramu rasa kasih dan sayang. Sesungguhnya pada yang demikian itu benar-benar terdapat tanda-tanda bagi kaum yang berpikir. ${ }^{34}$

Bimbingan pranikah diselenggarakan dalam rangka mempersiapkan calon pengantin, baik dari segi fisik atau psikis. Dalam meningkatkan kesejahteraan dan kekuatan keluarga, maka diperlukan ilmu pengetahuan tentang berbagai aspek yang menyangkut kehidupan keluarga, baik interaksi pola antar individu dalam keluarga maupun pola interaksi antar keluarga dalam sistem sosial yang lebih besar. Dampak bimbingan pranikah dalam memantapkan calon pengantin untuk mewujudkan keluarga sakinah di KUA Kota Salatiga yakni adanya persiapan dari calon pengantin yang dalam hal ini pasangan calon pengantin sebelum mengikuti bimbingan pranikah banyak hal yang tidak mereka ketahui tentang tugas-tugas suami isteri, hak dan kwajiban suami isteri, bagaimana cara mengatasi permasalahan dalam keluarga dan solusinya meminimalisir pertengakaran dalam keluarga dan untuk meminimalisir terjadinya perceraian. ${ }^{35}$

Jadi dengan bekal-bekal tersebut tentunya diharapkan dalam kehidupan keluarga bisa diterapkan dengan baik sehingga untuk sampai terjadinya suatu

\footnotetext{
${ }^{32}$ Wawancara dengan Kepala KUA Kota Salatiga

${ }^{33}$ Undang-Undang Perkawinan Nomor 1 Tahun 1974 Pasal 1

${ }^{34}$ Q.S. Ar-rum: 21.

${ }^{35}$ Wawancara dengan Kepala KUA Kota Salatiga
} 
perceraian bisa diminimalisir. Berdasarkan hasil wawancara yang penulis lakukan bahwa para calon pengantin mengaku bimbingan pranikah ini sangat bermanfaat untuk mereka pada akhirnya para calon pengantin ingin senantiasa berusaha semaksimal mungkin untuk mencapai kepada kehidupan keluarga yang sakinah yang dimana dalam Kompilasi Hukum Islam pada Pasal 3 bahwa perkawinan bertujuan untuk mewujudkan kehidupan rumah tangga yang sakinah, mawaddah, dan rahmah. ${ }^{36}$ Dalam menyikapi dampak ini ketika tidak dilaksanakan bimbingan pra nikah juga sesuai dengan kaidah fikih dimana dijelaskan:

$$
\text { درء المفاسد مقدم على جلب المصاح }
$$

Artinya: "Meninggalkan kerusakan harus didahulukan dari pada mengambil kemaslahatan" ${ }^{37}$

Jadi dalam bimbingan pra nikah tersebut adalah sebagai upaya untuk mencegah terjadinya suatu hal yang mudharat dalam suatu perkawinan yaitu mencegah terjadinya perceraian, dengan adanya bimbingan tersebut maka ketika itu semua dilaksanakan pastinya menjadi pelindung dalam kehidupan keluarga dan bisa tercapai kehidupan keluarga yang bahagia dan kekal berdasar Tuhan Yang Maha Esa.

\section{Simpulan}

Berdasarkan hasil penelitian tentang Urgensi Bimbingan Pra Nikah Bagi Calon Pasangan Pengantin Demi Terwujudnya Kehidupan Keluarga Sakinah, Mawadah, Warahmah (Studi Di KUA Kota Salatiga) maka penulis dapat menyimpulkan bahwa dalam proses pelaksanaan bimbingan pra nikah di KUA Kota Salatiga secara umum belum terjadwal secara rutin, sehingga tidak dapat ditentukan dalam satu tahun berapa kali penyelenggaraannya.

Bimbingan pra nikah tersebut terdapat dua macam yaitu bimbingan pra nikah yang dilaksanakan di Bimas Islam Kantor Kementerian Agama dan bimbingan pra nikah mandiri yang dilakukan oleh setiap masing-masing KUA. Materi yang disampaikan dalam bimbingan tersebut meliputi pengantin yang diberikan meliputi tujuh aspek yakni tata cara dan prosedur perkawinan,

\footnotetext{
${ }^{36}$ Kompilasi Hukum Islam Pasal 3

${ }^{37}$ Abdul Mudjib. Kaidah-Kaidah IImu Fiqh (A/-Qawa'idul Fiqhiyah), cet. ke-3. Jakarta: Kalam Mulia, 1999. hlm. 10.
}

JURNAL IQTISAD: Reconstruction of Justice and Welfare for Indonesia - Vol. 8 No. 2 (2021) 
pengetahuan agama, peraturan perundang-undangan dalam bidang perkawinan dan keluarga, hak dan kewajiban suami isteri, kesehatan dan reproduksi, manajemen keluarga, dan psikologi perkawinan dan keluarga. Dalam pelaksanaan bimbingan pra nikah oleh KUA Kota Salatiga mempunyai beberapa kendala antara lain kendala waktu dalam pelaksanaan bimbingan pra nikah dan kendala dana/anggaran dari pemerintah yang diberikan untuk pelaksanaan bimbingan pra nikah, sehingga dalam pelaksanaanya kurang maksimal serta masalah sarana dan prasarana di Kantor KUA yang kurang memadai.

Dalam pelaksanaan bimbingan pra nikah tentu sangat penting diberikan kepada calon pengantin dan itu sudah dilaksanakan oleh KUA Kota Salatiga. Karena tidak semua calon pengantin sudah paham tentang bagaimana cara berkehidupan dalam keluarga yang baik, cara mewujudkan keluarga yang sakinah, cara dalam mengatasi problem yang terjadi dalam keluarga dan masih banyak lagi hal-hal yang terkait dengan kehidupan keluarga diantaranya adanya pengetahuan baru bagi calon pasangan pengantin terkait bagaimana cara hidup dalam keluarga, pentingnya perkawinan dalam agama, cara memupuk kehidupan keluarga yang bahagia, cara menuju dan membentuk kehidupan keluarga yang sakinah, cara mengatasi problem dalam keluarga, pembinaan mental.

Dampak bimbingan pra nikah dalam memantapkan calon pengantin untuk mewujudkan keluarga sakinah di KUA Kota Salatiga yakni adanya persiapan dari calon pengantin yang dalam hal ini pasangan calon pengantin sebelum mengikuti bimbingan pra nikah banyak hal yang tidak mereka ketahui tentang tugas-tugas suami isteri, hak dan kwajiban suami isteri, bagaimana cara mengatasi permasalahan dalam keluarga dan solusinya meminimalisir pertengakaran dalam keluarga dan untuk meminimalisir terjadinya perceraian.

Jadi, dengan bekal-bekal tersebut tentunya diharapkan dalam kehidupan keluarga bisa diterapkan dengan baik sehingga untuk sampai terjadinya suatu perceraian bisa diminimalisir. Bahwa para calon pengantin mengaku bimbingan pranikah ini sangat bermanfaat untuk mereka pada akhirnya para calon pengantin ingin senantiasa berusaha semaksimal mungkin untuk mencapai kepada kehidupan keluarga yang sakinah. 


\section{DAFTAR PUSTAKA}

Al-Munawwar, Said Husin. Agenda Generasi Intelektual: Ikhtiar Membangun Masyarakat Madani. Jakarta: Pena Madani, 2003.

Amti, Prayitno, Erman. Dasar-dasar Bimbingan \& Konseling. Jakarta: Rineka Cipta. 2013.

Arifin. Pedoman Pelaksanaan Bimbingan dan Penyuluhan Agama. Jakarta: PT, Golden Trayon Press. 1998.

Arikunto, Suharsimi. Prosedur Penelitian. Jakarta: Bina Aksara. 1882.

Bimo, Walgito. Bimbingan dan Konseling Perkawinan. Yogyakarta: Andi Offset. 2004.

Dewa K. Sukardi. Pengantar Pelaksanaan Program Bimbingan dan Konseling di Sekolah. Jakarta: PT Rineka Cipta, Edisi Revisi. 2008.

Dirjen Bimas Islam, Peraturan Dirjen Bimas Islam No. DJ. II/ 491/ 2009 tentang Kursus Calon Pengantin.

Faridl, Miftah. "Merajut Benang Kaluarga Sakinah" dalam jurnal Al-Insan. 3 (2). Jakarta: Lembaga Kajian dan Pengembangan Al-Insan. 2006.

Ghozali, Abdul Rahman. Fiqh Munakahat. Jakarta: Kencana. 2010.

Hadari. Metode Penelitian Bidang Sosial Cet. Ke-8. Yogyakarta: Gajah Mada University Press. 1998.

Hamdany, Syubandono, Ahmad. Pokok-Pokok Pengertian dan Metode Penasehatan Pernikahan "Marriage Counseling". 1981.

Iskandar, M.Ridho. Urgensi Bimbingan Pra Nikah Terhadap Tingkat Pencerian. JIGC (Journal of Islamic Guidance and Counseling) Universitas Negeri Jakarta (UNJ), 2 (1). 2018.

Kartono, Kantini. Pengatar Metodologi Riset Sosial. Bandung: Madar Maju. 1996. 
Nastangin

Mahmudin, "Implementasi Pembekalan Pranikah Dalam membentuk Keluarga Sakinah Mawaddah Warahmah", Millah, Jurnal Studi Agama UII. XV, (2). 2016.

Page|146 Meoleong, Lexy J. Metode Penelitian Kualitatif. Bandung: Remaja Rosda Karya. 2013.

Mudjib, Abdul. Kaidah-Kaidah Ilmu Fiqh (Al-Qawa'idul Fiqhiyah), cet. ke-3. Jakarta: Kalam Mulia. 1999.

Nasution. Metode Reseach Penelitian Ilmiah cet Ke-IV. Jakarta: Bumi Aksara. 2001.

Peraturan Direktur Jenderal Bimbingan Masyarakat Islam Nomor : Dj.Ii/542 Tahun 2013 Tentang Pedoman Penyelenggaraan Kursus Pra Nikah.

Rahim, Faqih Aunur. Bimbingan dan Konseling dalam Islam. Yogyakarta:UII Press. 2001.

Shihab, Quraish. Wawasan Al-Quran. Bandung: Mizan. 2000.

S.L. La Sulo, dan Umar Tirtaraharja. Pengantar Pendidikan. Jakarta: Rineka Cipta. 2005.

Sugiyono. Metode Penelitian Pendidikan Pendekatan Kuantitatif, Kualitatif, dan R\&D Cet Ke-10. Bandung: Alfabeta. 2010.

Syahrur, Muhammad. Prinsip dan Dasar Hermeneutika Hukum Islam Kontemporer. Yogyakarta: Kalimedia. 2016.

Undang-undang Perkawinan Nomor. 1 Tahun 1974 tentang Perkawinan dan Kompilasi Hukum Islam. Bandung: Citra Umbara. 2011.

Wardah Nuroniyah, dan Wasman. Hukum Perkawinan Islam di Indonesia, cet. ke1. Yogyakarta: CV. Citra Utama. 2011. 